\title{
Left axillary artery pseudoaneurysm developing 1 year after a stab wound
}

\author{
Ufuk T. K. KORKMAZ1 ${ }^{1}$, Cemal TAŞLIGIL², Recep Y. BAYRAKTARLI ${ }^{3}$, Okan KISAOĞLU ${ }^{4}$
}

\footnotetext{
${ }^{1}$ Department of Cardiovascular Surgery, Karabük University, Karabük Training and Research Hospital, Karabük, Turkiye.

${ }^{2}$ Department of Physical Therapy and Rehabilitation, Kastamonu Physical Therapy Hospital, Kastamonu, Turkiye.

${ }^{3}$ Department of Radiology, Mogadishu Somalia Turkey Recep Tayyip Erdogan Training And Research Hospital, Mogadishu, Somalia.

${ }^{4}$ Department of Physical Therapy and Rehabilitation, Mogadishu Somalia Turkey Recep Tayyip Erdogan Training and Research Hospital, Mogadishu, Somalia.
}

\section{SUMMARY}

Axillary artery pseudoaneurysms are extremely rare. A 25-year-old male patient presented with pulsatile swelling that occurred 1 year after the injury of the left underarm, and left-sided pain, weakness, and difficulty in controlling the left hand. He had left axillary region with $7 \times 5 \times 3 \mathrm{~cm}^{3}$ pulsatile firm consistency, left hand 4/5 and left arm $3 / 5$ power loss, left hand holding no objects, and left arm not lifting up to the shoulder level. Color Doppler ultrasonography revealed left axillary artery pseudoaneurysm with dimensions of $56 \times 33 \mathrm{~mm}^{2}$ and luminal thrombosis about $40 \%$. Axillary artery, vein, and nerve suspension were taken after the left axillary artery was found and rotated. The organized thrombus within the sac was removed. Subsequently, aneurysmectomy and axillary artery primer repair were completed. This study aimed to discuss successful surgical repair and physiotherapy that started in the early period in the case that the arm and hand movement limitations were eliminated.

Key words: Axillary artery, primary repair, pseudoaneurysm, restricted movement, stab wound

\section{INTRODUCTION}

Arterial pseudoaneurysm occurs as a result of surgical interventions, infection, or trauma when the integrity of the arterial wall is impaired, resulting in limited blood supply to surrounding tissues. It is seen in the form of pulsatile masses containing a thrombus surrounded by a fibrous capsule that does not include all the arterial wall layers $(1,2)$. The most common cause of pseudoaneurysms is arterial trauma, and pseudoaneurysms in upper extremity peripheral arteries are seen much less frequently than those in lower extremity peripheral arteries (2). As upper extremity pseudoaneurysms can cause significant disabilities such as the loss of fingers or the upper extremity. Hence, diagnosis and surgical treatment are important (3). The pseudoaneurysm is formed of a fibrous capsule extending from the external wall. When a traumatic pseudoaneurysm is formed, it can create pressure on the surrounding nerve or vessel by expanding or lead to the formation of an embolism as thrombosis within the vessel and/or in the distal region (4).

This study discussed the successful surgical treatment of a patient with left axillary artery pseudoaneurysm, which developed 1 year after a stab injury. Considering the diagnosis, treatment, and rehabilitation applied to this patient in the light of information available in the literature, the study aimed to shed light on the vascular surgery applications in the patient's native place Somalia.

\section{CASE REPORT}

A 25 -year-old male patient presented with the complaints of a pulsatile, growing swelling below the left axilla, pain and weakness in the left arm, restricted movement of the left hand, and inability to raise the arm above the shoulder level. One year previously, the patient had sustained a stab injury to the left shoulder in Somalia and primary repair with skin sutures and bandage was performed by the local health care center.

The physical examination revealed a pulsatile mass, measuring $7 \times 5 \times 3 \mathrm{~cm}^{3}$ with a hard consistency, in the left axillary region (Fig. 1). Left brachial, radial, and ulnar pulses were palpable, with $4 / 5$ loss of strength in the hand and $3 / 5$ in the arm. Therefore, the patient could not grip objects with the left hand and could only raise his arm above the shoulder level with pain and difficulty. The laboratory test results were normal. Color Doppler ultrasonography showed a left axillary artery 


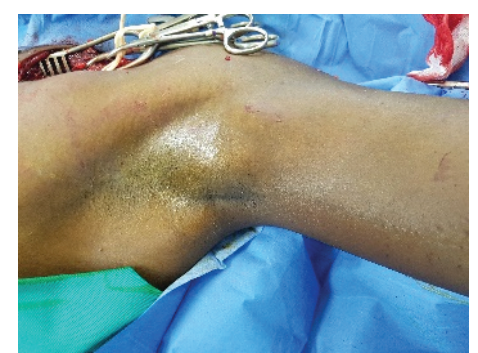

FIGURE 1: Pseudoaneurysm.

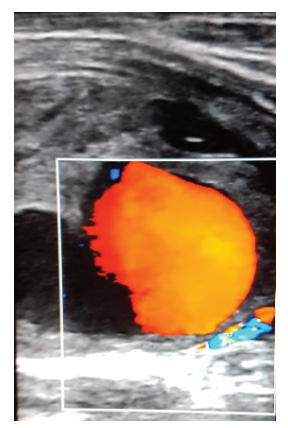

FIGURE 2: Doppler ultrasonography image.

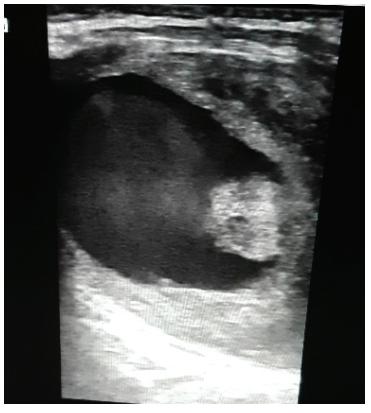

FIGURE 3: Ultrasonography image.

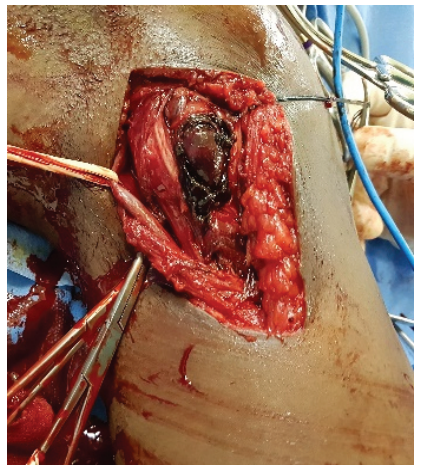

FIGURE 4: Intraoperative image.

pseudoaneurysm, $56 \times 33 \mathrm{~mm}^{2}$ in size, and approximately $40 \%$ of the lumen was thrombosis. A turbulent flow was determined in $60 \%$ section of the lumen that was clear (Figs. 2 and 3 ).

Based on these findings, pseudoaneurysm was considered to be related to the axillary artery in the left axillary region. Following the necessary preparation, the patient was admitted for surgery. An incision was made from the supraclavian region and the axillary artery was located and rotated under general anesthesia, as the pseudoaneurysm extended as far as the deep tissues in the axillary region, and it was difficult to reach the proximal axillary artery. The standard axillary region was stripped of thin skin tissue covering the aneurysm with a vertical incision, approximately $7 \mathrm{~cm}$ over the pulsatile mass.. The exploration of the aneurysmatic mass was completed by suspending the axillary artery proximally and distally
(Fig. 4). The axillary vein and nerve were also suspended. After the intravenous administration of 5000 units of heparin, proximal and distal vascular clamping was applied. Then, the pseudoaneurysm capsule was opened and the content was reached by making a direct incision over the mass. A large portion of the organized thrombus was removed from the surgical site.

The aneurysm sac was dissected, removed, and sent for histopathological examination (Figs. 5 and 6). Retrograde blood flow was noted in the artery. Primary repair was made with a vertical cut of approximately $1 \mathrm{~cm}$ in the axillary artery lumen. Following bleeding control, a MiniVac drain was applied the anatomical layers were sutured for closure, and the operation was concluded. The histopathological examination of the pseudoaneurysm revealed hematoma. The microbiological examination of the material taken from the aneurysm sac showed no production. The MiniVac drain was removed on the second postoperative day.

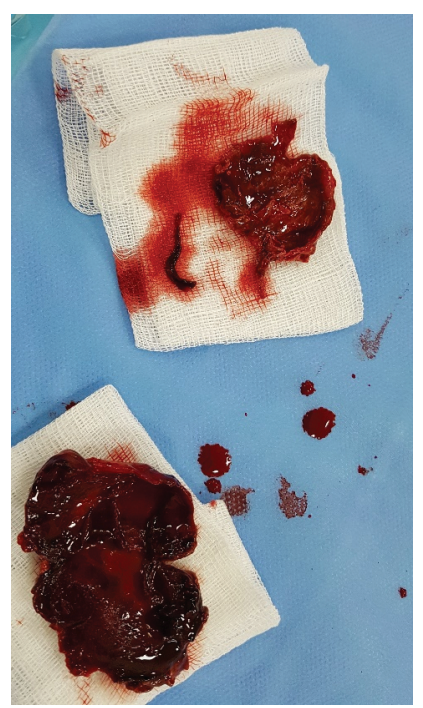

FIGURE 5: Organized thrombus and the pseodoaneurysm sac.

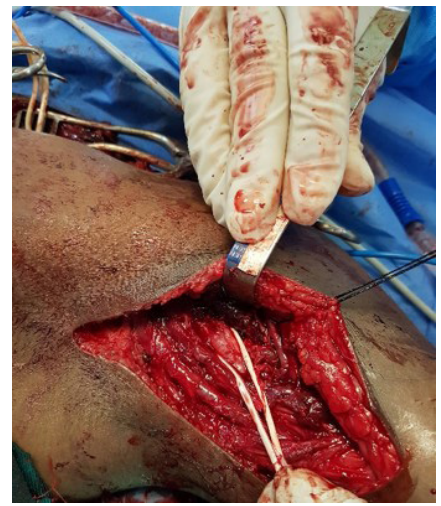

FIgURE 6: Appearance after the excision of the pseudoaneurysm. 
The left brachial, radial, and ulnar pulses were palpable. Neurology and Physical Therapy physicians were consulted because of the weakness and limited movement, which developed because of the nerve damage and restricted movement of the arm, probably caused by pressure on the nerve of the aneurysm during the stab injury. The patient was given physiotherapy support. He regained use of the arm with passive and active physiotherapy applications. Hospitalization was continued, although the wound had healed, because the patient had traveled a distance of $800 \mathrm{~km}$ and it would not be possible for him to return or receive physiotherapy at another center. At postoperative 1 month, the patient was instructed to apply physiotherapy at home and discharged with medications.

\section{DISCUSSION}

Upper extremity peripheral artery pseudoaneurysms are seen much less often than lower extremity peripheral artery pseudoaneurysms, and the most common reason is artery trauma (2). Axillary artery aneurysms are extremely rare, and the cause is generally blunt or penetrating trauma, chronic underarm crutch use, or postobstructive aneurysms in patients with thoracic outlet syndrome (5). Real axillary artery aneurysms with atherosclerotic causes are extremely rare. Axillary artery aneurysms can cause temporary or permanent neurological impairments as a result of pressure on the brachial plexus. In the present case, the pseudoaneurysm developed 1 year after a stab injury.

An important feature of these aneurysms is that they can cause thromboembolic complications $(5,6)$. The present case had complaints of a pulsatile mass below the left axilla and numbness in the left arm and forearm. Arterial pulses were present in the right upper extremity, and peripheral artery flow was seen to be normal on Doppler ultrasonography (USG) and in the physical examination. EMG was not applied because it was not available in the hospital.

Selective upper extremity arteriography is the most important diagnostic method in the trauma of the thoracic outlet vessels, obstructive lesions, and aneurysmal pathologies $(5,7,8)$. In addition to angiography, Doppler USG can be used for diagnosis (9). In the present case, the diagnosis was made with Doppler USG because angiography and other contrast imaging tests were not used in Somalia (Figs. 2 and 3).

Despite the use of endovascular techniques or interventions such as percutaneous thrombin injection in several vascular problems, the traditional surgical approach remains the best method $(8,10)$. The aim of the surgical approach should be primary aneurysmectomy and an arterial reconstructive intervention. Primary repair and revascularization with saphenous vein or end-to-end anastomosis should be selected in the reconstruction (11). The recent approach to the surgical treatment of axillary artery aneurysms is aneurysmectomy and interposition with a saphenous vein graft. Due to its proximity, care must be taken not to damage the brachial plexus $(4,10)$. In the present case, primary repair was sufficient after the aneurysmectomy. Following the successful surgical intervention without complications and after wound healing, physiotherapy and rehabilitation were started in the early period, enabling the patient to regain full use of the arm and hand with a full range of movement.

An axillary artery aneurysm should be surgically resected and treatment should be applied with the appropriate surgical technique to prevent extremity ischemia caused by neurological complications and thromboemboli. Physiotherapy and rehabilitation should be applied when necessary.

\section{REFERENCES}

1. Kırali K, Güler M, Mansuroğlu D, Ömeroğlu NS, Eren E, Özen Y, et al: Pseudoaneurysms of extremity arteries and treatments. Türk Göğüs Kalp Damar Cer Derg 2000;8:802-804.

2. Wielenberg A, Borge MA, Demos TC, Lomasney L, Marra G. Traumatic pseudoaneurysm of the brachial artery. Orthopedics 2000;23:1322-4.

3. Yetkin U, Lafçı B, İlhan G, Bayrak S, Gürbüz A. Brakiyal Arterde Geç Dönemde Gelişen Post Travmatik Yalancı Anevrizma ve Cerrahi Tedavisi. Türk Göğüs Kalp Damar Cer Derg 2004;12:58-6.

4. Canbaz S. Periferik arter anevrizmaları. In: Duran E, editör. Kalp ve damar cerrahisi. İstanbul: Çapa Tıp Kitapevi s. 783-98, 2004.

5. Tripp HF, Cook JW. Axillary artery aneurysms. Mil Med 1998;163:653-5.

6. Szuchmacher PH, Freed JS. Axillary aneurysms. N Y State J Med 1980;80:795-6.

7. Michalakis D, Lerais JM, Goffette P, Royer V, Brenot R, Kastler B. True isolated atherosclerotic aneurysm of the axillary artery. J Radiol 2003;84:1016-9. [Abstract]

8. Tetik Ö, Yetkin U, Yılık L, Özsöyler $Y$, Gürbüz A. Sağ üst ekstremitede kalıcı nörolojik hasara neden olan sağ aksiller arter psödoanevrizması: Olgu sunumu. Damar Cer Derg 2002;2:102-4.

9. Johnston RH Jr, Wall MJ Jr, Mattox KL. Innominate artery trauma: a thirty-year experience. J Vasc Surg 1993;17:134-40.

10. Kang SS, Labropoulos N, Mansour MA, Michelini M, Filliung D, Baubly MP, et al. Expanded indications for ultrasound-guided thrombin injection of pseudoaneurysms. J Vasc Surg 2000;31:28998.

11. Özsin Kadir K, Arıkan A, Meşe B, Karabörk O, Elde iskemiye neden olan spor yaralanmasına bağlı olarak geç dönemde gelişen ulnar arter psödoanevrizması: Olgu sunum, Turkish J Thorac Cardiovasc Surg 2011;19(4):634-636. 